\title{
Neonatal thyroid function: influence of perinatal factors
}

\author{
R C FRANKLIN, L M CARPENTER, AND C M O'GRADY \\ Departments of Paediatrics and Child Health, and Community Health, Wellington Clinical School, University \\ of Otago; and Radiochemistry Laboratory, Wellington Hospital, New Zealand
}

SUMmARY Indices of thyroid function were measured in 229 healthy term neonates at birth and at 5,10 , and 15 days of age. Results were analysed to assess whether maternal diabetes mellitus, toxaemia of pregnancy, intrapartum fetal distress, duration of labour, method of delivery, asphyxia at birth, race, sex, birthweight, birth length, head circumference, or method of feeding influenced any index. Thyroxine, the free thyroxine index, and free thyroxine concentrations at birth correlated with birthweight. Method of delivery influenced mean thyroxine and free thyroxine index values at birth and at age 5 days. Mean values of triiodothyronine, reverse triiodothyronine, thyroxine binding globulin, and thyroid stimulating hormone were not affected by any of the perinatal factors studied. Birthweight and perhaps method of delivery should be taken into account when interpreting neonatal thyroxine parameters but determination of thyroid stimulating hormone as a screen for congenital hypothyroidism in healthy term neonates circumvents these considerations.

Thyroid function is in a state of flux during the perinatal period. ${ }^{12}$ Previous studies $^{3-10}$ have documented thyroid hormone, thyroxine binding globulin and thyroid stimulating hormone concentrations in term and preterm infants at birth, over the neonatal period, and during early infancy. There are, however, very little data available which attempt to evaluate the possible effect of perinatal factors on neonatal thyroid function. ${ }^{11} 12$ This study aimed to determine whether maternal diabetes mellitus, toxaemia during the third trimester, intrapartum fetal distress, duration of labour, method of delivery, asphyxia at birth; or race, sex, birthweight, birth length, head circumference, and method of feeding influence parameters of thyroid function in healthy term neonates.

\section{Subjects and methods}

Two hundred and twenty nine singleton neonates born between 38 and 42 weeks' gestation (determined by maternal menstrual history) were studied. Informed maternal consent and approval of the Research Ethical Committee, Wellington Clinical School had been obtained. There were 117 European and 112 Polynesian infants; 126 were boys and 103 girls. Twelve infants were born to diabetic mothers and 25 after a pregnancy complicated by toxaemia during the third trimester. Twenty three babies experienced intrapartum fetal distress. Altogether 149 babies were unassisted vaginal deliveries, 30 were delivered by forceps, 29 by caesarean section after the onset of labour, and 21 by elective caesarean section. Seven had a 5 minute Apgar score of less than 7. All babies seemed to be gestationally mature; 166 were weight appropriate for gestational age, 36 were small and 27 large for gestational age. ${ }^{13} \mathrm{~A}$ total of 186 babies were wholly breast fed, while 43 were formula fed from birth. There were no clinical or management problems during the neonatal period.

Cord serum was collected at birth and capillary serum samples at 5,10 , or 15 days of age; these were held at $-20^{\circ} \mathrm{C}$ until assay. Thyroxine, triiodothyronine uptake, free thyroxine, triiodothyronine, reverse triiodothyronine, thyroxine binding globulin, and thyroid stimulating hormone concentrations were measured by radioimmunoassay. The methods and modifications used have been described in detail. ${ }^{14}$ The within assay and between assay coefficients of variation were: thyroxine $6 \%$ and $7 \%$, triiodothyronine uptake $3 \%$ and $4 \%$, free thyroxine $6 \%$ and $9 \%$, triiodothyronine $8 \%$ and $11 \%$, reverse triiodothyronine $6 \%$ and $11 \%$, thyroxine binding 
globulin $2 \%$ and $5 \%$, and thyroid stimulating hormone $6 \%$ and $13 \%$. The free thyroxine index was calculated as the product of thyroxine and triiodothyronine uptake.

Possible differences in the mean hormone concentrations at each time interval due to diabetes mellitus, toxaemia, intrapartum fetal distress, asphyxia at birth, race, sex, or method of feeding were examined by the two sample Student's $t$ test after logarithmic transformation of the hormone values. This transformation was done because the data were not normally distributed, and was consistent with previous reports. ${ }^{72}$ A similar examination for differences in the hormone means according to method of delivery was performed by one way analysis of variance. The linear relations between hormone concentrations and labour duration, birthweight, birth length, and head circumference were estimated by the method of ordinary least squares using the non-transformed hormone values, with the linear relations for birth length and head circumference being re-examined with birthweight included in the linear regression. Many tests were performed in the course of these analyses and so only results for which $\mathrm{P}$ was less than $0 \cdot 01$ were considered significant.

\section{Results}

The summary data of thyroid function for healthy term neonates at birth and at 5,10 , and 15 days of age are presented in Table 1. Maternal diabetes mellitus, toxaemia, labour duration, intrapartum fetal distress, asphyxia at birth, race, sex, or method of feeding had no significant influence upon any index of thyroid function at birth, or subsequently. Analysis of the hormone data according to method of delivery showed significant differences for thyroxine and free thyroxine index at birth (Table 2); the thyroxine and free thyroxine index mean values on day 5 of babies delivered by elective caesarean section were also significantly lower than those of babies delivered by other methods. The linear relations between cord thyroxine and birthweight [thyroxine $(\mathrm{nmol} / \mathrm{l})=0 \cdot 0148 \mathrm{~g}+94 \cdot 14, \mathrm{r}=0 \cdot 31$ ], cord free thyroxine index and birthweight [free thyroxine index $=0 \cdot 0117 \mathrm{~g}+77 \cdot 13, \mathrm{r}=0 \cdot 34]$, cord free thyroxine and birthweight [free thyroxine $(\mathrm{pmol} / \mathrm{l})=0.0009 \mathrm{~g}$

Table 1 Serum concentrations of thyroid hormones, thyroxine binding globulin (TBG), and thyroid stimulating hormone $(T S H)$ and values for triiodothyronine uptake (T3U) and free thyroxine index (FTI) in healthy term neonates at birth, 5,10 , and 15 days of age. Results are mean (SD)

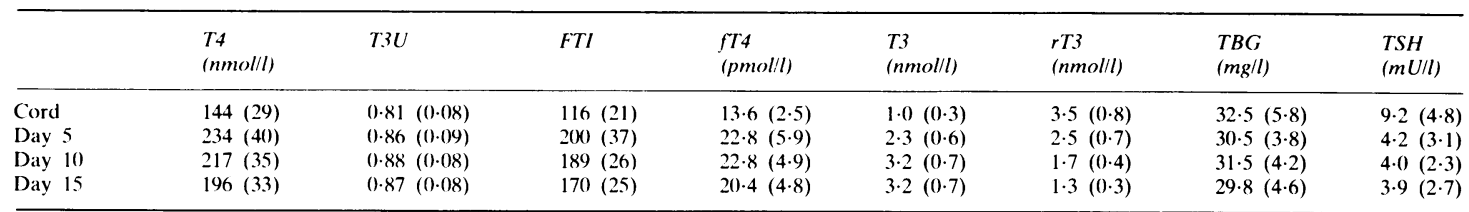

$\mathrm{T} 4=$ thyroxine: $\mathrm{fT} 4=$ free thyroxine: $\mathrm{T} 3=$ triiodothyronine: $\mathrm{rT} 3=$ reverse triiodothyronine.

Conversion-SI to traditional units: thyroxine $1 \mathrm{nmol} / \mathrm{l} \approx 0.08 \mu \mathrm{g} / 100 \mathrm{ml}$; triiodothyronine $1 \mathrm{nmol} / \mathrm{l} \approx 65 \cdot 1 \mathrm{ng} / 100 \mathrm{ml}$.

Table 2 Serum thyroxine, free thyroxine index and thyroid stimulating hormone values at birth, 5, 10, and 15 days of age according to method of delivery. Results are mean (SD)

\begin{tabular}{|c|c|c|c|c|}
\hline & $\begin{array}{l}\text { Unassisted } \\
(n=149)\end{array}$ & $\begin{array}{l}\text { Forceps } \\
(n=30)\end{array}$ & $\begin{array}{l}\text { Emergency caesarean } \\
(n=29)\end{array}$ & $\begin{array}{l}\text { Elective caesarean } \\
(n=21)\end{array}$ \\
\hline \multicolumn{5}{|c|}{ Thyroxine (nmol/l) } \\
\hline Cord & $148(28)$ & $127(28)^{*}$ & $147(33)$ & $130(19)^{*}$ \\
\hline Day 5 & $238(35)$ & $226(39)$ & $246(43)$ & $181(32)^{*}$ \\
\hline Day 10 & $216(36)$ & $207(36)$ & $231(43)$ & $212(29)$ \\
\hline Day 15 & $196(35)$ & $203(23)$ & $184(22)$ & $184(8)$ \\
\hline \multicolumn{5}{|c|}{ Free thyroxine index } \\
\hline Cord & $119(21)$ & $103(15)^{*}$ & $120(24)$ & $109(12)^{*}$ \\
\hline Day 5 & $205(34)$ & $188(30)$ & $208(38)$ & $156(28)^{*}$ \\
\hline Day 10 & $186(29)$ & $179(22)$ & $197(26)$ & $191(17)$ \\
\hline Day 15 & $170(28)$ & $165(19)$ & $170(15)$ & $175(8)$ \\
\hline \multicolumn{5}{|c|}{ Thyroid stimulating hormone $(\mathrm{mU} / \mathrm{l})$} \\
\hline Cord & $9 \cdot 5(4 \cdot 6)$ & $10 \cdot 5(5 \cdot 4)$ & $7 \cdot 5(5 \cdot 7)$ & $7 \cdot 8(2 \cdot 3)$ \\
\hline Day 5 & $3 \cdot 8(2 \cdot 8)$ & $3 \cdot 1(1 \cdot 8)$ & $5 \cdot 6(3.9)$ & $5 \cdot 7(4 \cdot 7)$ \\
\hline Day 10 & $3.6(1.6)$ & $4 \cdot 2(2 \cdot 6)$ & $4 \cdot 3(3 \cdot 0)$ & $4.8(2.9)$ \\
\hline Day 15 & $3.7(2.8)$ & $3.2(1.3)$ & $6.6(3.7)$ & $5 \cdot 1(1 \cdot 5)$ \\
\hline
\end{tabular}


$+10.59, r=0 \cdot 21]$, were significant, whereas the regression coefficients for birthweight and these hormone concentrations on days 5,10 , and 15 were not significant. The linear relations between cord thyroxine, free thyroxine index, and free thyroxine concentrations, birth length, and head circumference were not significant when the analyses were corrected for birthweight.

\section{Discussion}

These studies have shown that of the perinatal factors considered in healthy term neonates, only birthweight and method of delivery had significant effects upon indices of thyroid function. The positive correlation between birthweight and cord thyroxine confirmed results in previous studies, ${ }^{15}$ although comparisons between birthweight and thyroxine, free thyroxine index, and free thyroxine values on days 5,10 , and 15 showed that these correlations were transient. The significantly lower mean values for cord thyroxine and free thyroxine index observed in babies delivered by forceps or elective caesarean section were authentic as a second analysis of these data after adjustment for birthweight confirmed the observations. Previous studies $^{11}$ which have considered cord thyroxine values in relation to method of delivery have not shown significantly different values for babies delivered by caesarean section; however there was no differentiation between babies delivered by elective caesarean section and those delivered by caesarean section after the onset of labour. Infants delivered by forceps have not previously been categorised separately. The mechanism(s) by which the method of delivery may influence cord thyroxine and free thyroxine index values is not known, although studies in fetal sheep indicate that events during parturition may be relevant. The serum concentration of thyroxine rises in the lamb during the final hours of labour ${ }^{16}$ while delayed cutting of the umbilical cord is associated with a delay in the thyroxine surge observed immediately after birth. ${ }^{17}$ Further, the lower mean thyroxine and free thyroxine index values on day 5 of babies delivered by elective caesarean section, and the apparently attenuated thyroxine and free thyroxine index profiles observed in these babies compared with those seen in babies exposed to labour also suggest that parturition may have an influence upon the fetal thyroid axis.

These studies pertain to the assessment of thyroid function, particularly routine screening, in the neonate. It is appropriate, therefore, to consider the thyroxine and thyroid stimulating hormone results specifically. Neither parameter was influenced by maternal diabetes mellitus, toxaemia, labour duration, perinatal asphyxia, race, sex, or method of feeding. The recommendation that birthweight should be taken into account when interpreting cord thyroxine values ${ }^{15}$ is supported, although this consideration is probably not necessary in healthy term infants if thyroxine is measured on day 5 (present studies) or later (present study,). ${ }^{18}$ The observation that babies delivered by elective caesarean section had lower mean concentrations of thyroxine at birth and age 5 days requires further study to determine whether these infants often require repeat thyroxine or supplementary thyroid stimulating hormone measurements. In contrast, perinatal factors had no apparent effect on mean values of thyroid stimulating hormone. This observation together with those pertaining to thyroxine add to the argument favouring primary thyroid stimulating hormone measurement in the screening for congenital hypothyroidism.

We acknowledge support provided by the New Zealand Foundation for the Newborn and the National Children's Health Research Foundation.

\section{References}

' Fisher DA, Dussault JH, Sack J, Chopra IJ. Ontogenesis of hypothalamic-pituitary-thyroid function and metabolism in man, sheep and rat. Recent Prog Horm Res 1977;33:59-116.

2 Klein AH, Oddie TH, Parslow M, Foley TP, Jr, Fisher DA. Developmental changes in pituitary-thyroid function in the human fetus and newborn. Early Hum Dev 1982;6:321-30.

${ }^{3}$ Montalvo JM, Wahner HW, Mayberry WE, Lum RK. Se:um. triiodothyronine, total thyroxine, and thyroxine to triiodothyronine ratios in paired maternal-cord sera and at one week and one month of age. Pediatr Res 1973;7:706-11.

4 Erenberg A, Phelps DL, Lam R, Fisher DA. Total and free thyroid hormone concentrations in the neonatal period. Pediatrics 1974;53:211-6.

5 Cavallo L, Margiotta W, Kernkamp C, Pugliese G. Serum levels of thyrotropin, thyroxine, 3,3',5-triiodothyronine and $3,3^{\prime}, 5^{\prime}$-triiodothyronine (reverse $\mathrm{T}_{3}$ ) in the first six days of life. Acta Paediatr Scand 1980;69:43-7.

6 Jacobsen BB, Hummer L. Changes in serum concentrations of thyroid hormones and thyroid hormone-binding proteins during early infancy. Acta Paediatr Scand 1979;68:411-8.

7 Oddie TH, Bernard B, Klein AH, Fisher DA. Comparison of T4, T3, rT3 and TSH concentrations in cord blood and serum of infants up to 3 months of age. Early Hum Dev 1979;3:239-44.

${ }^{8}$ Cuestas RA. Thyroid function in healthy premature infants. J Pediatr 1978;92:963-7.

${ }^{9}$ Uhrmann S, Marks KH, Maisels MJ, et al. Thyroid function in the preterm infant: a longitudinal assessment. J Pediatr 1978;92: 968-73.

11' Pezzıno V, Filetti S, Belfiore A, Proto S, Donzelli G, Vigneri R. Serum thyroglobulin levels in the newborn. J Clin Endocrinol Metab 1981:52:364-6.

1 Erenberg A. The effect of perinatal factors on cord thyroxine concentration. Early Hum Dev 1978:2:283-9.

12 Byfield PGH, Bird D, Yepez R, Land M, Himsworth RL. Reverse triiodothyronine, thyroid hormone, and thyrotrophin concentrations in placental cord blood. Arch Dis Child 1978;53: $620-4$. 
${ }^{13}$ Buckfield PM, Clarkson JE, Herbison GP. Sex specific growth centiles at 28-42 weeks gestation New Zealand European infants. NZ Med J 1982:95:615-7.

14 O'Grady CM, Franklin RC. Thyroid hormone concentrations and free thyroxine status in neonatal venous and capillary serum pairs. Ann Clin Biochem 1984;21:306-9.

15 Bernard B, Oddie TH, Fisher DA. Correlation between gestational age, weight, or ponderosity and serum thyroxine concentration at birth. J Pediatr 1977:91:199-203.

16 Thomas AL, Krane EJ, Nathanielsz PW. Changes in the fetal thyroid axis after induction of premature parturition by low dose continuous intravascular cortisol infusion to the fetal sheep at 130 days of gestation. Endocrinology 1978;103:17-23.
17 Fisher DA. Thyroid physiology and function tests in infancy and childhood. In: Werner SC, Ingbar SH, eds. The thyroid. Hargerstown: Harper and Row, 1978;375-83.

${ }^{18}$ Kok JH, Hart G, Endert E, Koppe JG, De Vijlder JJM. Normal ranges of T4 screening values in low birthweight infants. Arch Dis Child 1983;58:190-4.

Correspondence to Dr R Franklin. Department of Paediatrics and Child Health. Wellington Hospital. Wellington, New Zealand.

Received 15 October 1984 